Journal of Jazz Studies vol. 10, no. 1, pp. 62-71 (Summer 2014)

\title{
Sentimental Journeys
}

\author{
Mark Burford
}

The Last Balladeer: The Johnny Hartman Story. By Gregg Akkerman. Lanham, MD: Scarecrow Press, 2012. 367 pp.

Sometime in the late 1970s, record producer Richard Gilbert approached baritone crooner Johnny Hartman in a Manhattan restaurant. Gilbert asked the singer to autograph his copy of John Coltrane and Johnny Hartman, the album that became Hartman's greatest popular triumph, then pitched the idea of an LP featuring Hartman singing ballads backed by a small jazz combo on one side and disco arrangements of standards on the other. The venture was ill fated from the start. "The disco bubble broke," Gilbert remembered, and after recording two of the dance tracks, "Beyond the Sea" and "Caravan," he pulled the plug. "It was simply put aside." Even allowing for the bizarrerie of this aborted project, the episode nonetheless captures revealing aspects of the career documented in Gregg Akkerman's biography, The Last Balladeer: The Johnny Hartman Story: respected artistry; an ambivalent co-presence of balladry, jazz, and pop; music industry figures not quite sure what to do with Hartman; unfortunate timing; the 1963 Coltrane album that remained a point of reference throughout Hartman's remaining two decades of work; the sense of unfinished business; and, in the middle of it all, an unmistakable voice.

Just out of curiosity, I asked a friend in her mid-thirties, someone whose taste in singers I respect highly, what she thought of Hartman. She was perplexed by what sounded like a trick question. To her, Hartman's greatness as a singer was self-evident, a conviction that suggests the valuable contribution of The Last Balladeer to popular music literature. The pleasure taken in Hartman's singing is a Credo of sorts: a profession of belief in the eloquent understatement of balladry, in the lasting vitality of the Great American Songbook, and in the virtues of unapologetic surrender to the sentimental lure of a love song. To savor the sheer sensuousness of the nether regions of Hartman's voice-which Akkerman likens to a cello-and not be an occasional sucker for old-school candlelit romance seems incoherent. Yet Hartman's forty-year career, despite its considerable, if dispersed, peaks, was often as shaky as his present-day reputation seems secure. Accordingly, Akkerman is unambiguous about his motivations and goals. Beginning with

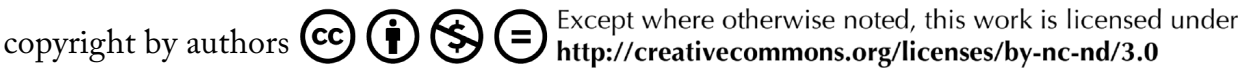


the question that lingers like a haunting refrain in commentary on Hartman"Why was he not a bigger success in his lifetime?"-and with a conviction that the singer "deserved better," Akkerman endeavors to clarify the facts about Hartman's personal and professional life and ultimately "to award him posthumous merit" (xiv).

Hartman was born in Houma, Louisiana in 1923, but as an infant moved with his family to South Side Chicago as part of the Great Migration (Chapter 1). His musical career is perhaps best understood as unfolding in three acts with extended intermezzi: the decade from 1946 to 1956 that saw Hartman struggle to capitalize on his most promising opportunities for success as a popular vocalist (Chapters 3-6); a brief but prestige-heightening straw fire of recognition in the mid-1960s when Hartman became "almost famous" following the acclaim of the Coltrane album (Chapters 8-9); and a final period from the mid 1970s until his too-early death from lung cancer in 1983, during which Hartman, with pianist Billy Taylor as a devoted champion, earned the status of a connoisseur's singer, appreciated by many as a masterfully suave, they-don't-sing-'em-like-that-anymore classic (Chapters 11-13). Each of these periods, respectively, can be associated with an album that, in Akkerman's view, represents an artistic, if not always commercial, high point: Songs from the Heart (Bethlehem, 1956), John Coltrane and Johnny Hartman (Impulse, 1963), and the Grammy-nominated Once in Every Life (Bee Hive, 1980). In between, Hartman experienced stretches with significant recording droughts: first when he returned from an extended European tour in 1959 only to discover "I'd been forgotten" (Chapter 7) and a slightly later period, dating from the end of his relationship with ABC-Paramount in 1966, when he did not enter the studio for six years (Chapter 10). A decisive postlude to the Hartman story was the rediscovery and elusive popular success that came when Clint Eastwood featured the music from Once in Every Life in the acclaimed 1995 film The Bridges of Madison County, with Hartman's voice sounding the burgeoning illicit passion between the characters played by Eastman and Meryl Streep (Chapter 15).

Despite his best efforts, Hartman never quite attained the popular fame either of the established balladeers who were his models-principal among them, Frank Sinatra, Nat "King" Cole, Perry Como, and Billy Eckstine—or of slightly younger contemporaries like Mel Tormé, Tony Bennett, or Roy Hamilton, who were reshaping the mold and redrawing the boundaries between jazz, pop, and ballad singing in distinctive ways. Akkerman describes the fits and starts as Hartman tried to make it in the music industry after his 1946 discharge from a racially discriminatory U.S. Army where, Hartman remembered, "I really started my professional singing career" (Chapter 2). 
Hartman's post-military period is in certain respects the heart of the story and could be told in multiple ways. All things put together, Hartman's opportunities to make a name for himself in the late-1940s and 1950s would have been the envy of many singers. Picking up gigs initially as a production singer in Chicago's black nightclubs, Hartman won a local talent competition at the El Grotto that brought him his first significant attention and eventually landed him a spot in the band of Earl Hines. Hartman gained valuable seasoning touring with Hines, making a notable splash at Harlem's Apollo Theater in 1947, but he was back on his own when Hines dissolved the band to join Louis Armstrong's All-Stars. After moving to New York, Hartman was handpicked by Dizzy Gillespie to tour with his band in 1948-49. Reversing the role played by Armstrong with Fletcher Henderson in the mid-1920s, when Henderson played Armstrong's hot trumpet off of his orchestra's sweet sound, the relaxed lyricism of Hartman's numbers, interspersed with the band's high octane bop arrangements, provided a tempering change of pace that Gillespie hoped "would further increase the popularity of our sound" (36). It should also be noted that Gillespie was at the time also integrating musical elements that established his ensemble as a pioneering Latin jazz band. The 1949 recordings "I Should Care" and "That Old Black Magic" exhibit a blend of Hartman's supple baritone, darting bop fills, and Afro-Cuban instrumentation and rhythmic sensibilities.

In the 1940s and 1950s, Hartman recorded with the Hines and Gillespie bands and in a number of other contexts for a range of labels. Akkerman, correcting several sources, identifies Hartman's very first recordings as a pair of sides cut in February 1947 in Chicago for Sunbeam under the guidance of producer/bandleader Marl Young. But a bevy of recording sessions followed: MGM and King Records with the Hines band, Mercury with Erroll Garner and with Jimmy Carroll (the latter sides, including the lovely "S'posin'," produced by Mitch Miller), Apollo with George Williams, and a trove of recordings stockpiled for Regent in late 1947 just prior to the second PetrilloAFM recording ban. Hartman's sides with Gillespie were recorded for RCA Victor and generated enough interest that the major label signed Hartman as a solo artist in 1951. RCA backed Hartman with the orchestras of Norman Leyden (unidentified in the book) and Perez Prado, aggressively hyped him as a "gold mine" with "Sinatra type appeal for the gals," and anointed Hartman as the label's "answer to Billy Eckstine" (72). In 1955-56, Hartman made his first solo LPs for the jazz specialty label Bethlehem Records, including the ravishing Songs from the Heart, which, absent the shared spotlight on the later Coltrane album, is arguably the best and most focused display of Hartman's distinctive gifts. A blurb on the back cover of The Last Balladeer refers to 
Hartman as "the most undeservedly neglected vocalist in the history of twentieth-century popular music." Perhaps. Hartman was no doubt a victim of both circumstance and the singularity of his sound, but in the fifties singers made it by scoring hit singles or albums, and at face value it seems difficult to argue that Hartman never had a fighting chance to do so. When one reads the book's chronicle of the quantity and quality of promising affiliations early in Hartman's career that did not quite pay off, especially his stint with RCA, something more complicated and enigmatic than bald neglect seems to be at play.

"Johnny Hartman did everything right and had the chops to back it up," Akkerman writes in his final chapter. "When [phenomenal success] doesn't come, the question gets asked: 'Why?" (260). His explanation for this state of affairs emphasizes mishandling and misunderstanding of Hartman's talents, as indicated by chronically unsound repertory, production, and marketing choices. At Mercury, "there was little promotion" and Hartman's better sides were "not provided enough label support" $(48,60)$. At Regent, "the quality of Hartman's repertoire was hindering his professional advancement," with releases that "featured nothing that would become a hit" (61). At RCA, there were "several missteps and a narrow vision" that betrayed a "lack of conviction regarding how to effectively market" Hartman. "RCA Victor's botched attempt" to push Hartman's recording of "Wheel of Fortune," when "the reality was that [Kay] Starr's was the better version," came at the expense of the "excellent 'Lemme Go," and as a result, the label "missed out on having a hit with either" (73, 75). Bethlehem's unquestioned commitment to artistic quality was cut off at the knees by "a stupefying lack of promotional funding" (87). Even later, Royal Roost "was guilty of not offering any tangible promotional support" for the 1959 album And I Thought About You (105). For Hartman's solo LPs produced in the afterglow of the Coltrane album, Impulse/ABC-Paramount failed to exert "enough promotional effort to put the music in front of the public;" instead they subtly repackaged the singer as a pop-crossover act that "only served to alienate Hartman's hard-won jazz fans" (143). And, the author adds: "It certainly would have helped if $\mathrm{ABC}$ had found him more TV appearances and used its influence to acquire him bookings at Vegas-style showrooms" (153).

Based on his impressively exhaustive consideration of the recorded evidence, Akkerman reaches the conclusion-one he believes record companies should have reached as well—that an "intimate jazz sound" was the ideal setting for Hartman's voice, that "he was never more effective than when surrounded by a small combo and one prominent horn player" $(141,174)$, which is, of course, precisely his backing on John Coltrane and Johnny Hartman. 
Since reception history is one of the book's central pillars, Akkerman has left no stone unturned in documenting and closely interpreting critical commentary in trade publications, both on Hartman's recordings and on his live performances, identifying recurring themes and, when he feels necessary, pushing back on the judgment of "critics and musicians [who] were unable to see beyond a narrow agenda" (249). There is nothing to suggest that Akkerman's assessments of record label decisions and critical judgments are off base per se, though at times the recurring speculation about more fruitful directions in the life being written about begins to feel like an exercise in "shoulda, coulda, woulda" that creates an awkward triangulation of subject, author, and reader.

Interestingly, as with Gillespie, Hartman's collaboration with Coltrane's "classic" quartet of pianist McCoy Tyner, bassist Jimmy Garrison, and drummer Elvin Jones marked a calculated popular turn. After Coltrane's first two albums with Impulse, producer Bob Thiele, intent on demonstrating that Coltrane was a "great and complete jazz artist" (115), recommended a more straight ahead slate of LPs that resulted in Ballads, Duke Ellington and John Coltrane, and eventually John Coltrane and Johnny Hartman-the only album the saxophonist ever made with a vocalist. Rejecting other possible singers, including Sarah Vaughan, Coltrane chose Hartman out of admiration for his artistry and in recognition that the singer, now forty, was due an opportunity for a "comeback." For Akkerman, the album, to which he refers by its catalog number "A-40," is both shrouded in and haloed by legend. He devotes the first half of Chapter 8 to debunking a series of resilient myths: that Coltrane and Hartman had previously worked together in the Gillespie band (their tenures did not overlap); that either Hartman or Coltrane chose all of the songs (it was a collective effort); that Coltrane's heart was not in the project ("these ballads that came out were definitely ones which I felt at this time," he quotes Coltrane as saying); that the entire album was recorded in one take (Akkerman has identified alternate takes of every track); and that a cache of mystery tracks has been withheld by Impulse (the only unreleased song was "Afro Blue," the masters of which are now lost). The second half of the chapter offers a discussion of the album's best known cuts-"My One and Only Love" and the song that became a signature Hartman tune, Billy Strayhorn's "Lush Life"and a roundup up enthusiastic commentary about the album by luminous critics. In this chapter, two qualities that pervade the book, Akkerman's determination to set the record straight and his open advocacy for Hartman's reputation and significance as an artist (teetering at certain moments toward hagiography), come through particularly clearly. Akkerman is himself a pianist and singer and his personal investment in and identification with Hartman's 
journey is communicated in strikingly open terms in the book's final sentences: "Johnny, thanks for letting me get to know your beautiful family, your close friends, and, of course, for songs from the heart. Like thousands of fans all over the world, you've made my life a little nicer and a lot more romantic" (270).

The strength of The Last Balladeer lies in the seriousness, diligence, and sense of responsibility that the author brings to his project. Akkerman has combed the extant primary and secondary sources on Hartman, tracked down official records, and conducted interviews with family members and key musical associates, including Hartman's second wife Theodora "Tedi" Hartman and his longtime accompanist Tony Monte. His indefatigable research enables him to correct persistent factual errors and reconstruct much of Hartman's wide-ranging performance history, including nightclub gigs, major television appearances, civil rights benefits, his stab at acting, and overseas engagements. Hartman, we learn, enjoyed particular favor in Japan, where he became an "icon" over the course of three productive tours, with Art Blakey and the Jazz Messengers in 1963, and as a solo act in 1972 and 1977. During the 1972 tour, Hartman recorded a pair of excellent LPs finally released together in 2005 as The Tokyo Albums. Especially valuable is the discography that appears in an appendix. Many of Hartman's albums became newly available during the $\mathrm{CD}$ era, but a surprising number of recordings remain difficult to lay hands on. Once in Every Life, for example, can only be pieced together from two Bridges of Madison County-related compilations. In the case of such hard-to-find items as Hartman's first-ever record, "The Song You Sing" b/w "Always Together," released as the now "incredibly rare" Sunbeam 108, Akkerman has tracked down copies from collectors. Demonstrating a commendable non-selectivity - he has listened to virtually everything Hartman recorded-Akkerman has also located bootleg recordings in various archives and private collections, giving him a more complete picture, including a sense of Hartman as a live performer. In a second appendix, Akkerman has provided a list of all songs ever recorded by Hartman, a wise addition in the case of a singer who, like his biographer, became an increasingly passionate advocate of the Great American Songbook. In his later years, Hartman seemed to view this repertory as a stable shelter amid the welter of music industry flux. "Well, thank God for people who still remember the old Cole Porter songs and all those beautiful tunes," he told Frank Kofsky in 1978, expressing gratitude as well for younger fans he was winning on the college circuit. "These kids are saying, 'My God, this music is great. Where have they been hiding this?"' $(205,212)$.

In the course of his narrative, Akkerman touches on several fascinating broader topics germane to Hartman's career. Looming large in the first half of 
the book is the flesh, blood, and, specter of Eckstine, the Pittsburgh-born singer who at midcentury was in some ways every bit as formidable a popcultural presence as Sinatra. In both the Hines and Gillespie bands, Hartman filled a role that had been occupied, physically and conceptually, by Eckstine. Hartman effectively became Eckstine's replacement when Eckstine left Hines to strike out on his own and form a progressive jazz ensemble in which Gillespie was a featured trumpeter and arranger. A comparison of Eckstine's "I Stay in the Mood for You" (1944) and Hartman's "I Should Care" suggests that in hiring Hartman, Gillespie sought to replicate the dialogue of bop and pop that had been a distinguishing feature of the Eckstine band. Akkerman calls the inescapable comparisons with Mr. B that were faced by virtually every postwar black crooner "the Eckstine factor." As vocalese master John Hendricks recalled, and as RCA's marketing of Hartman underscores, "Billy was big. Bigger than Frank. Hartman was in his shadow, and that was a hell of a big shadow" (27). Hartman was praised both for sounding like and resisting the influence of Eckstine, and Akkerman hints at Hartman's ambivalent position - a stumbling block throughout much of his career that, as it turned out, served him well in future decades — of being both the next and the last in line.

The question of this lineage offers much to unpack. Hartman's taste in vocalists crossed racial lines-he cited Bob Eberle, Jack Leonard, Dick Haymes, Como, and Sinatra as favorite vocalists right alongside Joe Williams, Pha Terrell, Cole, and Eckstine - but the endeavor of becoming a black balladeer presented special challenges. Among these was the sexual politics of race, particularly in the South where some enthralled white female fans would confess to Hartman furtively: "Gee, I wish you weren't Negro." As Hartman said in a 1975 interview, echoing near identical comments by Eckstine and others, African American male entertainers seemed more easily linked to buffoonery and bestial lust than humanizing romance: "You get the feeling that you're never supposed to be serious or be a man who could fall in love" (6364). ${ }^{1}$ One wishes that Akkerman had rolled up his sleeves and fleshed out his fleeting references to the "neo-crooner school" that emerged around 1950 (65) and to the "black crossover crooner" (72). He writes that Hartman's expressed admiration for Terrell, who recorded most notably with Andy Kirk and His Clouds of Joy, was significant because Terrell was an African American vocalist "known more for crooning than for stereotypical blues or gospel

\footnotetext{
${ }^{1}$ For a discussion of Eckstine and the challenges of the black balladeer, see Mark Burford, "Sam Cooke as Pop Album Artist-A Reinvention in Three Songs," Journal of the American Musicological Society 65 (2012): 113-178 (especially 141-55).
} 
singing" (68). But Hartman's comment was an opportunity to go further and help the reader understand the significance of being "the last balladeer" by providing historical context that acknowledged some of the other trailblazing black popular singers active in the 1930s and 1940s whose careers preceded and overlapped with Eckstine's, among them Harlan Lattimore with the Don Redman Orchestra, Orlando Roberson with Claude Hopkins, Dan Grissom with Jimmie Lunceford, Ruble Blakey with Lionel Hampton and Don Byas, Leroy "Bing" Williams with Freddie Williams, and Al Hibbler with Duke Ellington. Akkerman occasionally falls into the unfortunate trap of casually and uncritically referring to pop singing as "white," flattening out a more multilayered history and replicating the very racial discourse that complicated the careers of Hartman and his brotherhood of musical forbears. Like these singers, Hartman had to navigate the aesthetic requirements, market demands, and cultural politics of a dense thicket of explicitly and implicitly racialized vocal practices: blues, jazz, pop, balladry, torch singing, rhythm and blues, and eventually rock and roll. Indeed, Akkerman's title places the issue of style front and center. This is refreshing since the question of categories is too often and too easily dismissed as mere pedantic pigeonholing. In reality, the music industry's stylistic labels, however arbitrary, involved concrete, career altering artistic and promotional decisions-sometimes in the vocalist's hands, and other times not. Hartman grappled with the questions of his style and artistic range-the perception that he couldn't swing, for instance - throughout his career. On the one hand, he told John Wilson of the New York Times in 1982: "I'm an all around singer ... I studied classical music. I go back to the heavy spirituals" (43). On the other, in the same interview he acknowledged that with Gillespie's band he "didn't fit in with bebop so I just went on singing ballads" (39). Hartman even acknowledged some reluctance about working with Coltrane: "Knowing that John was a strict jazz musician and I was a ballad singer," he was unsure "if John could play the kind of stuff I did" $(116,133)$. Hartman appeared to own the fact that stylistically he was, and was resolved to remain, a specialist. Akkerman highlights Hartman's "ballad-bravura" by quoting Nick Catalano, who remembered Hartman as "the only singer who could sing ten ballads in a row in a nightclub" and get away with it. In the late 1950s, Hartman was building a career not only in competition with a horde of pop album artists but also contemporaneously with the increasing popularity of black gospel singing. Whatever his early familiarity with the "heavy spirituals" (he attended Chicago's Holy Trinity Missionary Baptist Church with Dinah Washington), in the 1970s he acknowledged: "I was a cool singer even when I sang in church. That was just me, my style of singing. It wasn't none of the hollering and screaming" (4). 
The book's driving narrative is, perhaps, how Hartman's career was continuously answerable to, yet also repeatedly called into question by, the fine gradations between pop, jazz, and ballad singing. One gets a sense of the professional challenge Hartman and his various record labels faced when considering that he started off seeking fame as a mainstream pop singer, made his name as a jazz vocalist, worked regularly as a cabaret artist, and was persuaded to dabble pragmatically in rock and roll (e.g., "Teach Me to Cry" and "Bye, Baby, Bye" for ABC-Paramount), all the while insisting that he was at heart a pure balladeer.

Akkerman's overriding concern is the question of why Hartman was not more famous. For Ackerman, success seems predicated on critical acclaim and publicity, and his nose sometimes gets a bit too buried in the chatter of reviews and press coverage. As a result, he misses opportunities to pull back the lens and better situate Hartman historically, socioculturally, or even musically. Some research less narrowly focused on Hartman may have better equipped Akkerman to interpret his findings and develop his analysis. For his discussion of engineer Rudy Van Gelder's studio, where the remarkable intimacy of the Coltrane album was captured, instead of settling for soundbites by Van Gelder ("it was a nice place to play") and Tyner ("he was amazing ... one of the greatest engineers we've ever had") (121-22), Akkerman might have consulted Dan Skea's work on Van Gelder's equipment and methods. ${ }^{2}$ Claiming that in the mid-1950s "the music industry was still driven greatly by singles, and the LP was often not viewed by record companies as a necessity" paints an undernuanced and even inaccurate picture since, as Keir Keightley has shown, by this time the LP format had already in fact become a core commodity-not to mention tailor-made for an artist like Hartman. ${ }^{3}$ The 1950 s were a golden age of popular vocalists: in minimizing the presence of contemporaneous stars like Eddie Fisher, Joni James, Roy Hamilton, Doris Day, Mario Lanza, Vaughan Monroe, Rosemary Clooney, or Della Reese in his narrative Akkerman may have succeeded in underscoring the distinctiveness of Hartman's identity as a balladeer, but he also constricted the reader's perspective on Hartman's professional choices and what he was up against in the eyes of music consumers. Lastly, the Johnny Hartman story is indeed a fascinating and profitable one to recount, but The Last Balladeer is not always an elegant read. The book's publisher commends Akkerman's “conversational style” of writing,

\footnotetext{
${ }^{2}$ Dan Skea, "Rudy Van Gelder in Hackensack: Defining the Jazz Sound in the 1950s," Current Musicology nos. 71-73 (Spring 2001-Spring 2002): 54-76.

${ }^{3}$ Keir Keightley, "Long Play: Adult-Oriented Popular Music and the Temporal Logics of the Post-War Sound Recording Industry," Media, Culture, and Society 26 (2004): 375-91.
} 
though this feels somewhat euphemistic in light of occasionally inelegant prose (e.g., Songs for the Heart has a "transcendental quality" (85), "the melody has an inherently lingering quality" in "The Maquerade" (141), etc.) and the deployment of too many redundant and minimally informative quotations, all suggesting the need for more editorial intervention. I'm not sure that we need quite so many witnesses to vouch for the fact that Hartman was a "nice guy."

Despite these shortcomings, Akkerman has written an earnest and very well researched book that takes the music seriously and breaks important scholarly ground on one of the most instantly recognizable vocal artists of the past half-century. The accomplishments and vagaries of Hartman's career are worthy of close study on their own merits, though they also offer a unique vantage point on the postwar music industry, the diversity of popular vocal practices, and the politics of style. Even if he has not followed some paths of inquiry as far as one might hope, Akkerman should be commended for illuminating several promising trailheads for future scholars.

\section{About the Contributor}

MARK BURFORD is Associate Professor of Music at Reed College. His work on popular music in the U.S. and European concert music has appeared in the Journal of Musicology, 19th-Century Music, Musical Quarterly, Current Musicology, and the Journal of the American Musicological Society. He is currently writing a book on the circulation and reception of black gospel singing within U.S. popular culture during the 1950 s and early 60 s.

The Journal of Jazz Studies (JJS) is published by the Institute of Jazz Studies at the Newark campus of Rutgers, The State University of New Jersey. JJS is hosted online by the Rutgers University Libraries at http://jjs.libraries.rutgers.edu. 